\title{
Challenge and Opportunity of Islamic Educational Institution in Globalization Era
}

\author{
Makhful \\ Universitas Muhammadiyah Purwokerto, Indonesia \\ makhfulfai@gmail.com
}

\begin{abstract}
Globalization is not really a new phenomenon for Muslim in Indonesia. The source of globalization is from the Middle East especially Mecca, Medina, and Cairo from the late of $19^{\text {th }}$ century until the early $20^{\text {th }}$ century. However, nowadays, the globalization that happens and afflicts in Muslim society In Indonesia shows different source and character. Globalization process is no longer coming from the Middle East, but from the Western that keeps holding the supremacy and hegemony in many fields for people in the world. From the contexts explained, how is the challenge and opportunity of Islamic education in Indonesia? How is the position of Islamic educational institution?
\end{abstract}

Keyword: Challenge and Opportunity of Islamic educational institution

\section{INTRODUCTION}

Nowadays, we find that our life is in the extended of 'World's Settlement', yet it still is easy to be explored. Therefore, anything that happens in the other side of 'World's Settlement' will affect the value system in Indonesia. The world's globalization is indeed bringing pretty much amenities for Indonesian. (Suyanto, 2000 : 212). System and global communication network lead us to the simplicity to access current information that is necessary to sustain daily life.

Both globalization and the future era are and will affect the development of social and culture in Muslim society and Islamic education (including pesantren) in Indonesia. Muslim society cannot avoid the process of globalization itself, especially if they want to survive and be successful in the development of competitive world.

Globalization is not really a new phenomenon in Muslim society in Indonesia. The source of globalization is from the Middle East especially Mecca, Medina, and Cairo from the late of $19^{\text {th }}$ century until the early $20^{\text {th }}$ century. However, nowadays, the globalization that happens and afflicts in Muslim society in Indonesia shows different source and character. Globalization process is no longer coming from the Middle East, but from the Western that keeps holding the supremacy and hegemony in many fields for people in the world. [1].

From the contexts above, how is the challenge and opportunity of Islamic education in Indonesia? How is the position of Islamic educational institution?

\section{Challenge}

Islamic educational system in Indonesia faces the basic challenges. Therefore, it needs continuous renewal effort. If the Islamic educational system cannot carry its task, then the function of national education is lost.

The basic challenges according to [2] are as follow:

1. Can Islamic educational system in Indonesia becomes the center of excellence of science and technology and also the source of teaching Qur'an and Sunnah development? For example, can the health experts engineering health, donating the body equipment without violating aqidah and syari'ah? Can the banking experts bring the capital system forward without riba?

2. Can the Islamic educational system becomes the renewal center of Islamic thought which is really able to respond the challenges in every eras without neglecting the dogmatic that must be followed?

3. Can the Islamic education experts grow and develop the personality that includes faithful and righteous to God, equipped with the scientific reasoning ability which does not have time limitation?

The effort to catch up the scientific and technology field does by technology shift, buys license to produce goods in the market using science and technology that have been prepared by license seller who is in the charge of making their own technology. The use of advanced tools already become certainty and menace at the same time. It makes us left behind if we do not use those tools, yet if we use it without even knowing the basic things, it will make the dependency grows bigger.

Moreover, the use of advanced technology will expand the gap between lower and upper line if those things are linked to the condition of Islamic culture that has not fully modern yet. Although the technology is used to conventional prominence, the menace of dependency is still not yet realized. However, if it related to the use of high technology such as biotechnology, microelectronic and nuclear, it will be realized that our national educational system is still weak in the science and technology field. [3]

The branch of knowledge becomes a basic compound for science and technology mastery which do not have proper and equitable achievement and payment yet. Some decision makers consider that basic science such as mathematics, physics, chemistry and biology, are less 
relevant to overcome the urgent of social and economic needs. The youth generation is also less interested in entering mathematics and science faculty.

There are only few number of science and technology expert. They also do not have much time to think and develop the theories. That is our shortage to appreciate science and scientists more by respect them and fulfill their economic needs. No wonder that Indonesian who has the Doctor degree will eventually hit the road to Malaysia, consider that in the country a professor will get the salary more less 48 millions. While in Indonesia, the salary is more less Rp. 2.400.000,-. Nowadays, still related to certificate, it is estimated that millions of Islamic youth generation has an abysmal education, as the result of limitation work in farming land and of expansion work in industrial area.

\section{Opportunity}

However, the Islamic educational system in Indonesia has big opportunities to encounter globalization era.

1. Islamic educational system in Indonesia does not face the domination of national educational system because Islam, philosophically, is never contrary to the national's viewpoint of life. In the concept of forming UUSPN number 2 in 1989 of government regulation, the opportunity to have self-development is widely open.

2. Pancasila as the national principle philosophically is the part of Islamic philosophy.

3. In the more stable circumstance, whether physical, law, security and economic, is an appropriate opportunity for the majority to fill it.

4. The renewal of Islamic thought is developing. The rise of Ikatan Cendekiawan Muslim Indonesia (ICMI) practically can be used as the new tool to strengthen the discourse[2].

Thus, in terms of teaching and sociology of education, Islamic educational system in Indonesia is adequate to be a national education sub-system as desired. It is needed to be aware that in the majority, there are both 'opportunity' and 'load' in the high passion of conducting modern Islamic studies, where our rationality becomes infatuated modern side, is possible to be realized.

It is needed to be aware that education cannot stands alone without the other fields that have to be turned a finger harmonically and systemically toward the same national goals, so the wisdom and expertise in cooperate with various experts in various disciplines and courses are very much needed. The fact is many non-Muslim people can do their life exactly in Islamic way, yet in the other way, the Muslims themselves are not Islamic in their behavior. Nowadays, Muslims need to be open minded in order to have rational mind and accept the criticism for sake of improvement.

\section{The Position of Islamic Educational Institution}

The fact that Indonesia has $85 \%$ Muslim community makes the existence of Islamic educational institution very perceptible. As an institution which leads someone to be strongly educated with normative principle in a long time, the education institution carries a big responsibility [4].

In fulfilling short term target, Islamic institutions have to provide facilities to lead the mass of students to be Islamic people who are able to face and undergo the change. Meanwhile for long term target, the emphasize is that the Islamic educational institutions have to put forth the consistent scholar, teacher, and parents to show their ability to guide and lead their children to be a progressive generation in the world and have a base in hereafter life (Ibid). Therefore, what is the Islamic educational institution we need? Islamic institution in the future must avoid idealistic framework because the determinations of those aspect are not apart from policy and practice of education politics in Indonesia. Nevertheless, the border line of education institution at least is equivalent to the development of social life problem including religion in society.

The first side is about qualification problem of teachers. According to Islamic educational institution adviser, the aspect in the present and future is those who not only understand religion contextually well, but also textually and also know the development of science in common. There must be clear qualification of the main review goals that has to be reached. It is including the institution which produces Islamic educational staff.

On the other side, the qualified teachers must prove their ability by avoiding cognitive target in learning process, because affective and psychomotor are the determinant of morality and behavior realization in the character development of students as a scholar, people in education and parents among the society in the future.

From this context, the existence of teacher in every educational level has a big responsibility demand compared to other professions [5]. However, their existence will be surrounded by responsibility to create national educational goal which assertively leads to morality target, skill, and intelligence.

It is the challenge that needs answer. If the problem overcomes, it will solve more tackled. Our assumption is that a change is necessary and becomes a form of life quality improvement which must be achieved by human being. Yet a change that gives negative impact for the society usually happens because they are unprepared and shocked because it is contrary with cultural value and belief system.

Considering the phenomenon aforementioned, Islamic educational institution still has the other shortcomings. It has a weakness in answering challenge in every era and it needs to be fixed. The aim is not to compete, but to fulfill and undertake responsibility to put forth wise, intellectual and have a good morality human beings, also as an anticipation to lessen the marginality in global association.

Regardless of the rapid science and technology development, at least in the last few decades, there are many people who are interested in learning religions and spiritual teachings. Since the stray situation as the result 
of rapid change in all life aspects, many people feel stat they need something great to be held. If almost every religious and spiritual teaching revived in every way, it is not required.

Related to the latest development in religions of the world, it does not need to be worried about the future of Islamic educational institution. However, the system and capacity of Islamic education have to be improved so that it can fulfill the needs of modern world. By developing exact aspect, it hopes Islamic education to give a better contribution to human being.

In modern era, the system of Islamic educational institution must be renewed, the curriculum must be developed by putting various, qualitative, and interesting topics. Some aspects of Islamic teachings and its legacy are seen as the main branch of humanity science which includes the field of religion, philosophy, ethic, spiritual, literature, archeology art, history. Each of these fields can be done hostilely, in the start, in the middle, classical, modern, and so on. [1].

There is a possibility to develop the fields of Islamic study to other fields of social science. The original sources exist to prove the truth of the fields related to Islam such as economic, politics, sociology, international relation and so on. It very much needs to improve exact sciences in Islamic study program, because Islam has plenty of inheritance in those fields. Field such as mathematics, astronomy, medical, chemistry, geography and physics are really developing because there is an intentional purpose between the early development of exact sciences and modern development. Thing that needs to be noticed is how the methodology and concept can be as equal as the other sciences.

By doing those things, Islamic study program is not only being seen as Islamic theology program or Islamic law research. Ideas and legacy of Islam in the fields explained before can be contextualized in real problems faced by Islamic community and world people.

At the same time, the new teaching methodology introduced. This method can push to analyze and criticize about what they get from education or learning. They can form a self point of view and have a new paradigm. As the result, they can develop a fresh thought to fulfill the needs of contemporary society.

With those reasons above, provision of teaching staffs must be improved qualitatively. Most of teacher needs a lot of qualification improvement and increases their knowledge about the current development. Half of them are sent to well-known universities in the West, where they can get training in teaching about writing methodology, interpreting and analyzing. By doing those things, it will avoid them from the innocence, excessive behavior and backwardness about the development and needs of modern people.

\section{CONCLUSION}

In order to face the future challenge of Islamic education in Indonesia, it should be realized that the globalization influence brings interdependence between each related sides. Therefore, every side or party has to stand firmly as its identity. It can be done by having open minded, supple and wise thought in cooperation with various sides.

Everyone has only one national educational system. Nevertheless, it does not mean that there is only one institution as a single administrator in national education. All of the educational activities, whether it is managed by government or private, are sub-system in national education. The formulation of national education is formulated more detail in national education formulation of national educational system regulations number/1987. It still becomes an open formulation for a further interpretation development.

Considering the various challenges, so the function of Islamic educational institution is to grow and develop self learning ability for students in order to build the identity up and carry the future out.

\section{REFERENCES}

[1] Azyumadi Azra, Pendidikan Islam Tradisi dan Modernisasi Mernuju Milenium Baru. Jakarta. PT. Logos Publishing House. 1994

[2] Mastuhu, Memberdayakaa Sistem Pendidikan Islam. Jakarta. Logos Wacana Ilmu.. 1999

[3] Ahmad Baiquni, Islam dan Pendidikan Nasional. Jakarta. Lembaga Penerbitan IAIN. 1983.

[4] Muslih Usa dan Aden Wijaya (et, at), Pendidikan Islam dalam Peradaban Industrial. Yogyakarta. Adicita Karya Nusa. 2000

[5] S.Nasution, Djihad Hidyam, Pendidikan di Indonesia Memasuki Milenium III.Yogyakarta. Adicita Karya Nusa. 2000

[6] Abdurahmansyah, Sintesis Kreatif Pembaharuan Kurikulum Pendidikan Islam. Yogyakarta. Global pustaka Utama. 2002.

[7] Achmad Djainuri, Pendidikan dan Modernisasi di Dunia Islam. Surabaya. Al-Ikhlas. 2001

[8] Fazlul Rahman, Islam dan Modenitas. Bandung. Pustaka. 2000

[9] __ Konstrovensi Pemikiran Fazlur Rahman (Studi Kritis Pembaharuan ) Pendidikan Islam. Cirebon. Pustaka Dinamika. 1999

[10] Ghulam Nabi Saqib, Modernization of Muslim Education. Lachre. Islamic Book Service. 1969

[11] Moechtar Buchori, Pendidikan dalam Pembangunan. Yogyakarta. Pt Tiara Wacana. 1996

[12] Marwan Saridjo, Bunga Rampai Pendidikan Aganma Islam. Jakarta. CV. Amissco. 1996 